\title{
Alcohol consumption in early adolescence and medical care
}

Alcohol, the product of cereal or fruit fermentation, has been used for thousands of years by different civilizations, such as the Egyptians, the Chinese, the Greco-Romans, and Pre-Columbian cultures, among others, either for rituals or social recreation. The Greek civilization hosted the Dionysian mystery cults in which participants sought to get close to their god through the use of intoxicants. In Roman mythology, Dionysus was known as Bacchus, and his name continues to be present in bacchanals, in association with debauchery or lack of inhibition, typical of acute alcohol intoxication. (Picture 1)

In the Middle Ages, alcoholic beverages were known as "spirits" and were widely used with healing purposes. ${ }^{1}$ During the $18^{\text {th }}$ century, alcohol consumption increased among the population, favored by the laws promoting the use of cereals to make distilled beverages, in addition to the growing industrial development of civilizations.

In the $19^{\text {th }}$ century, the attitude changed and was accompanied by campaigns promoting moderate alcohol use. Thus, alcohol manufacture, sale, import, and export were even prohibited in some countries. The "Prohibition" brought into the fore alcohol illegal trade and smuggling in response to market demand, which eventually resulted in the Prohibition annulment. In Argentina, a special prohibition is made in the hours before and after an election.

At present, in our society, alcohol is the psychoactive substance most commonly used by adolescents. ${ }^{2}$ Several studies agree that between $49 \%$ and $76 \%$ of 10 - to 14 -year-old adolescents have drunk alcohol, ${ }^{3-5}$ and at this age group adolescents are most vulnerable for alcohol use initiation. This occurs across Argentina and is replicated in other Latin American countries. The World Health Organization (WHO) recommends abstinence from alcohol consumption in youth under 18 years of age because the later alcohol use starts, the lower the risk for future dependence. Consistent with present laws in place in Argentina that prohibit the sale of alcohol to minors under 18 years of age, it is evident that we are in the face of a complex public health problem. In addition, the current alcohol drinking modality among adolescents follows a risky and abusive pattern, especially over the weekends, in the night hours, and while out with their peers, which is amply

FIgURE 1: "The Triumph of Bacchus" by Velazquez, 1629 painting, at the Museo del Prado, Madrid. It represents Bacchus as the god who offers wine to men, temporarily releasing them from their problems, in allusion to the intoxicating effect of alcohol

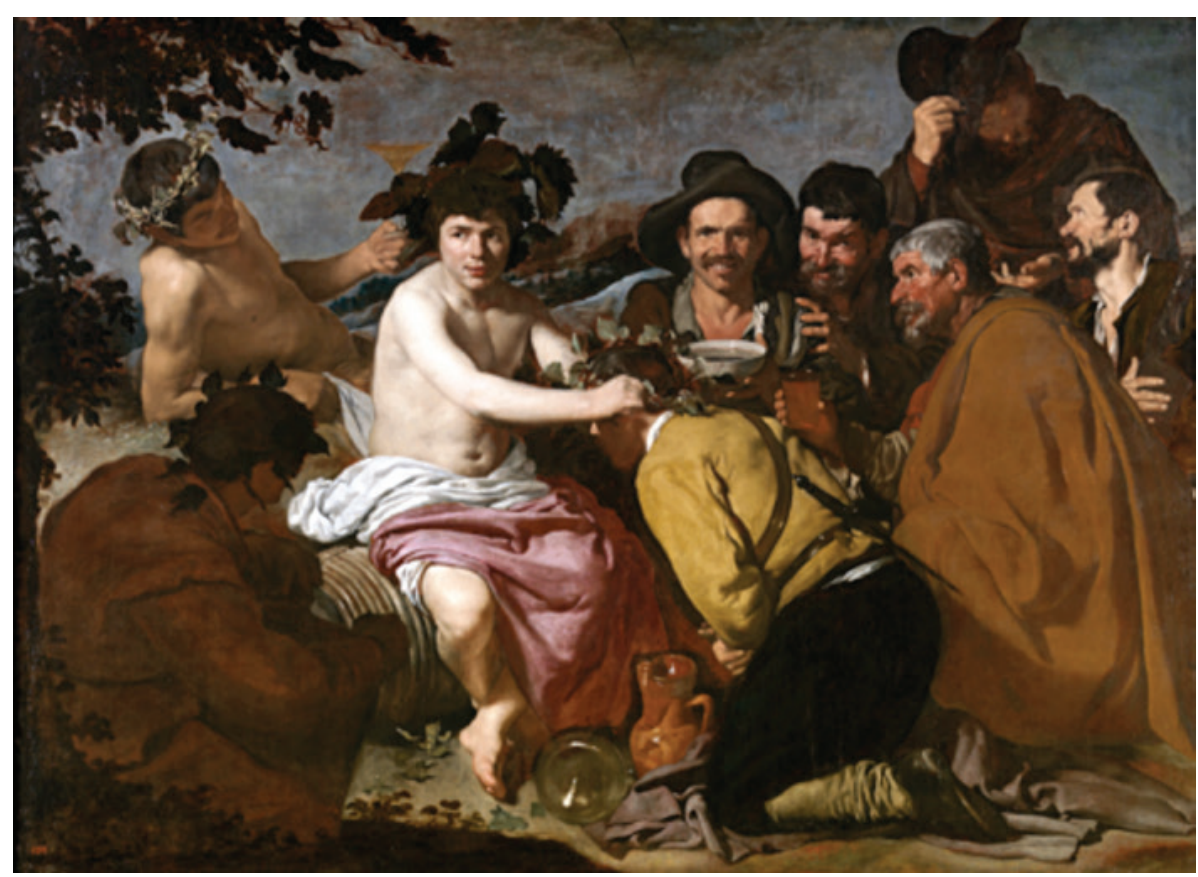


tolerated by their family and environment. ${ }^{5,6}$ Such heavy episodic drinking-HED- (it refers to drinking large alcohol amounts over a few hours) is typical of adolescents and youth who go out on the weekends and aims at acute alcohol intoxication, preferably with high alcohol content distilled beverages, such as vodka, gin or tequila, ${ }^{5}$ sometimes mixed with medication, known as the "jarra loca" ("the crazy jar"). ${ }^{7}$ This drinking modality results in acute alcohol intoxication, and youth in such state bring about a higher rate of traffic accidents, more violent episodes, either within the family environment or on the streets, unintended pregnancies, and sexually transmitted infections. It is also necessary to consider the effect of illegal substances or medications, which are commonly used together with alcohol.

In the context of HED, adolescents drink high alcohol content beverages and rapidly reach high blood alcohol concentrations, which are reflected in a fast altered level of consciousness. Alcoholic coma is a frequent reason for admission to emergency room services among youth who have not developed alcohol tolerance, i.e., occasional or episodic alcohol users. This situation is an example of a frenetic, uncontrolled consumption, which is observed day to day in our society.

Alcohol and drug use prevention should be approached and understood from the overall concept of Health Education. ${ }^{8}$ It is fundamental to create risk awareness programs focused on discussing the risks of episodic, abusive alcohol drinking. Borras Santiesteban pointed out a lack of documentation that would enable establishing alcohol use among adolescents, and the absence of coordination between the health sector and schools, emphasizing the need to develop adolescent-centered primary care. Another aspect that stands out from the same author's article is that the most common channel for access to information on alcohol use prevention was TV, leaving health care staff out of the picture. This demonstrates that mass media play a very important role in the distribution of information regarding sensitive health issues, including addictions, and should be coordinated with health care providers specialized in this field.

Silvia Cabrerizo, M.D.

Pediatrician, Toxicologist

National Poison Control Center

Hospital Nacional Prof. Alejandro Posadas

http:/ /dx.doi.org/10.5546/aap.2016.eng.396

\section{REFERENCES}

1. Contreras Morales CA, del Campo MC. Productos de la fermentación alcohólica; un beneficio para la salud [Internet]. [Accessed on: June 10 ${ }^{\text {th }}, 2016$ ]. Available at: http://bibliotecadigital.usbcali.edu.co/ jspui/bitstream/10819/2613/1/Fermentaci\%C3\%B3n \%20 alcoh\%C3\%B3lica $\% 20$ un $\% 20$ proceso_Carlos $\% 20$ Contreras_USBCTG_2015.pdf

2. Secretaría de Programación para la Prevención de la Drogadicción y la Lucha contra el Narcotráfico. Sexto Estudio Nacional sobre Consumo de Sustancias Psicoactivas en estudiantes de enseñanza media. Buenos Aires: SEDRONAR; 2014. [Accessed on: June 13 ${ }^{\text {th }}, 2016$ ]. Available at: http://scripts.minplan.gob.ar/octopus/ archivos.php? file $=4121$

3. Schaffer C, Arizaga V, Albarenque M, Haseitel B. Alcoholismo en la adolescencia. Revista de Posgrado de la VIa Cátedra de Medicina 2004;139:24-8. [Accessed on: June $\left.10^{\text {th }}, 2016\right]$. Available at: http://med.unne.edu.ar/revista/ revista139/alcohol.htm

4. Argentina. Ministerio deSalud dela Nación. Lineamientos para la atención del consumo episódico excesivo de alcohol en adolescentes. Buenos Aires: Ministerio de Salud de la Nación; 2012. [Accessed on: June 10 $0^{\text {th }}, 2016$ ]. Available at: http://www.msal.gob.ar/saludmental/images/stories/ info-equipos/pdf/2012-10-31_lineamientos-atencionalcohol.pdf

5. Cabrerizo S, Varela S, Lutz MI. Encuesta sobre abuso de alcohol y medicamentos en adolescentes de cuatro escuelas del conurbano bonaerense. Arch Argent Pediatr 2014;112(6):504-10.

6. Míguez HA. Patrones culturales de la alcoholización social en estudiantes bonaerenses. Vertex Rev Argent Psiquistr 2009;20(87):325-8.

7. Cabrerizo S, Docampo PC.Alcohol y mezcla de fármacos: modalidad de abuso frecuente. Arch Argent Pediatr 2010;108(5):e111-3.

8. Pons Diez J, Berjano Peirats E. El consumo abusivo de alcohol en la adolescencia: un modelo explicativo desde la psicología social [Internet]. [Accessed on: June 10 ${ }^{\text {th }}, 2016$ ]. Available at: http://www.msssi.gob.es/alcoholJovenes/ docs/consumoAbusivo.pdf 